\title{
A TÚRÁZÁS HUMÁNMETEOROLÓGIAI SZEMPONTBÓL: 2. RÉSZ: GYAKORLATI ALKALMAZÁSOK
}

\author{
Ács Ferenc \\ ELTE Meteorológiai Tanszék, 1117 Budapest, Pázmány Péter sétány 1/A \\ e-mail: acs@caesar.elte.hu
}

\section{Bevezetés}

Az emberek számára az időjárás a hőterhelés szempontjából fontos. Ez a mindenkori reggeli „hogyan is öltözködjek ma?” kérdésben testesül meg. Az időjárást, mint kültéri hőterhelést, döntően az aktuális makrocirkulációs típus határozza meg, melynek két alapvető fajtája a ciklonális és az anticiklonális típus. A ciklonális makrocirkulációs típusokban kisebb az időjárás hőterhelésének intenzitása, de nagyobb az időjárás hőterhelésének változékonysága, mint az anticiklonális makrocirkulációs típusokban. Az extrém hőterhelések (nagy hőtöbblet vagy nagy hőhiány) az anticiklonális makrocirkulációs helyzetekben vannak. Ekkor a höterhelésnek nemcsak az intenzitása, hanem az időtartama is nagyobb az átlaghoz képest. A továbbiakban mi csak az anticiklonális makrocirkulációs időjárási helyzetekre (1. ábra) fókuszálunk.

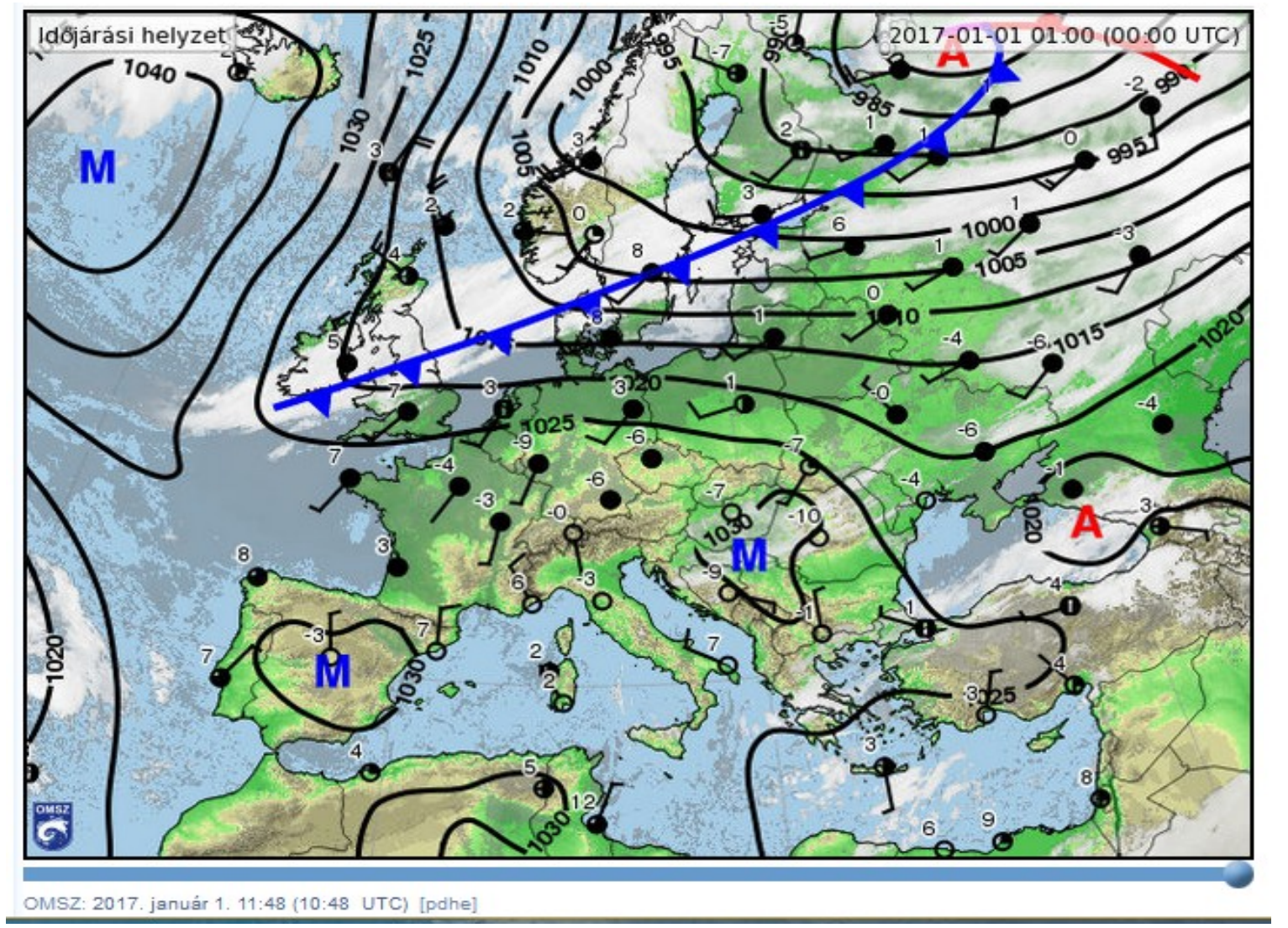

1. ábra: Egy Kárpát-medence feletti anticiklonális makrocirkulációs helyzet

Európára vonatkozó időjárási képe 2017. január 1-jén 0 UTC-kor.

Az időjárás hőterhelésének érzékelése változik embertől emberig, még akkor is, ha megegyező a mozgásállapotuk (pl. ugyanakkora sebességgel gyalogolnak). E szubjektív jelleg, 
azaz, az időjárás hőterhelésének egyén-specifikus érzékelése egy olyan témakör, amely közhelynek számít a mindennapi élet beszélgetéseiben. E tanulmány célja e témakör tudományos megközelítése (pl. Jang et al., 2009) abban az esetben, ha az ember gyalogol, túrázik, azaz mozgási sebessége $4 \mathrm{~km}^{\text {óra }}{ }^{-1}$. A témát számszerüen fogjuk elemezni e tanulmányt megelőző 1. részben (Ács, 2016) bemutatott modell alapján.

\section{Adatok}

A modell bemenő adatai mind a humán jellemzők, mind a légköri hőterhelést meghatározó változók.

\section{Humán jellemzök}

A humán jellemzők az ember testének tömege, magassága, az ember életkora és neme, valamint az emberi test mellmagasságban mért kerületével megegyező henger átméröje $(d)$ és a maximális, fenntartható mozgási sebesség $\left(\alpha_{M}\right)$. A mérésekben résztvevő emberek névsora és adataik az 1. táblázatban láthatók. Az adatokat Újvidéken gyüjtöttük 2018. július 12-én reggel nyolc és kilenc óra között a nyári időszámítás szerint. A maximális, fenntartható mozgási sebességet 50 m-en becsültük a megtett út időtartamának mérésével. Látható, hogy a $d$ szórása aránylag kicsi, viszont az $\alpha_{M}$ szórása jóval nagyobb. Megemlítendő, hogy a mérésekben résztvevő emberek átlagos életkora 55,6 év.

1. táblázat: A modellben használt humán jellemzők 10 vajdasági (délvidéki) emberre vonatkozóan. $d=$ az emberi test mellmagasságban mért kerületével megegyező henger átmérője, $\alpha_{M}=$ a fenntartható maximális mozgási sebesség.

\begin{tabular}{|l|c|c|c|c|c|}
\hline Név & Tömeg [kg] & Magasság [cm] & Kor [év] & $\boldsymbol{d}[\mathbf{m}]$ & $\boldsymbol{\alpha}_{\boldsymbol{M}}\left[\mathbf{m} \cdot \mathbf{s}^{-1}\right]$ \\
\hline 1. Szabó-Török Emma & 58,0 & 152,0 & 60 & 0,28 & 2,82 \\
\hline 2. Szücs Rita & 55,0 & 166,0 & 34 & 0,23 & 2,54 \\
\hline 3. Muhi Béla & 95,0 & 186,0 & 68 & 0,34 & 3,81 \\
\hline 4. Brindza Ervin & 93,0 & 192,5 & 54 & 0,32 & 5,47 \\
\hline 5. Malagurszki Éva & 65,0 & 172,5 & 52 & 0,25 & 4,39 \\
\hline 6. Pásztor Lajos & 95,0 & 179,0 & 53 & 0,34 & 5,01 \\
\hline 7. Futó Attila & 88,0 & 178,0 & 53 & 0,33 & 4,70 \\
\hline 8. Kerekes György & 85,0 & 176,0 & 59 & 0,33 & 4,77 \\
\hline 9. Deák Ildikó & 78,0 & 169,0 & 47 & 0,28 & 4,56 \\
\hline 10. Popović Teodor & 82,0 & 171,0 & 76 & 0,32 & 3,01 \\
\hline
\end{tabular}

\section{Légköri kényszer}

Mint ahogyan már említettük, a hőterhelést meghatározó légköri változók anticiklonális idöjárási helyzetre vonatkoznak: egy nyári és két téli napra (2. táblázat). A változókat tudományos irodalom, közvetlen megfigyelés és az Országos Meteorológiai Szolgálat (OMSz) honlapján közzétett adatok alapján becsültük. A $Q_{0}$-t és az $\alpha$-t Mihailović és Ács (1985) munkájából vettük a hónap és az óraköz ismerete alapján, az óra-közbeni, túrázási időszakra vonatkozó relatív napfénytartamot $(n / N)$ és felhőzetet $(N)$ megfigyelés alapján, míg a léghőmérsékletet $\left(T_{a}\right)$, a relatív nedvességet $(r)$ és a $10 \mathrm{~m}$-es szélsebességet $(u)$ az OMSz honlapján közzétett adatok alapján becsültük. A mellmagasságban $(1,5 \mathrm{~m})$ levő szélsebességet az $u$ alapján becsültük a neutrális rétegződésre vonatkozó logaritmikus szélprofil feltételezésével. Vegyük észre, hogy a két téli nap adott óraközökre vonatkozó időjárása merőben különböző! 
A január 1-jei nap fő jellegzetessége a köd, a vele járó vízgőztelítettség és a szélcsend, míg a január 7-ei nap teljesen napsütötte, a levegő száraz, a szél erősebb. E különbségek gyönyörüen látszanak a 2. ábrán.

2. táblázat: A modellben használt légköri kényszerek, melyek 2016. augusztus 9-én 15-16 óra, 2017. január 1-jén 10-11 óra és 2017. január 7-én 13-14 óra közötti időszakra vonatkoznak.

\begin{tabular}{|c|c|c|c|c|c|c|c|}
\hline Nap & $\boldsymbol{Q}_{\boldsymbol{0}}\left[\mathbf{M J} \cdot \mathbf{m}^{-\mathbf{2}} \cdot\right.$ óra $\left.^{-\mathbf{1}}\right]$ & $\boldsymbol{\alpha}$ & $\boldsymbol{n} / \boldsymbol{N}$ & $\boldsymbol{N}$ & $\boldsymbol{T}_{\boldsymbol{a}}\left[{ }^{\circ} \mathbf{C}\right]$ & $\boldsymbol{r}[\mathbf{\%}]$ & $\boldsymbol{u}\left[\mathbf{m} \cdot \mathbf{s}^{-1}\right]$ \\
\hline 2016.08 .09$. & 1,905 & 0,31 & 0,6 & 0,2 & 28 & 40 & 2,20 \\
\hline 2017.01 .01$. & 1,503 & 0,42 & 0 & 1 & $-5,0$ & 100 & 0,80 \\
\hline 2017.01 .07$. & 1,344 & 0,39 & 1 & 0 & $-9,0$ & 40 & 3,60 \\
\hline
\end{tabular}

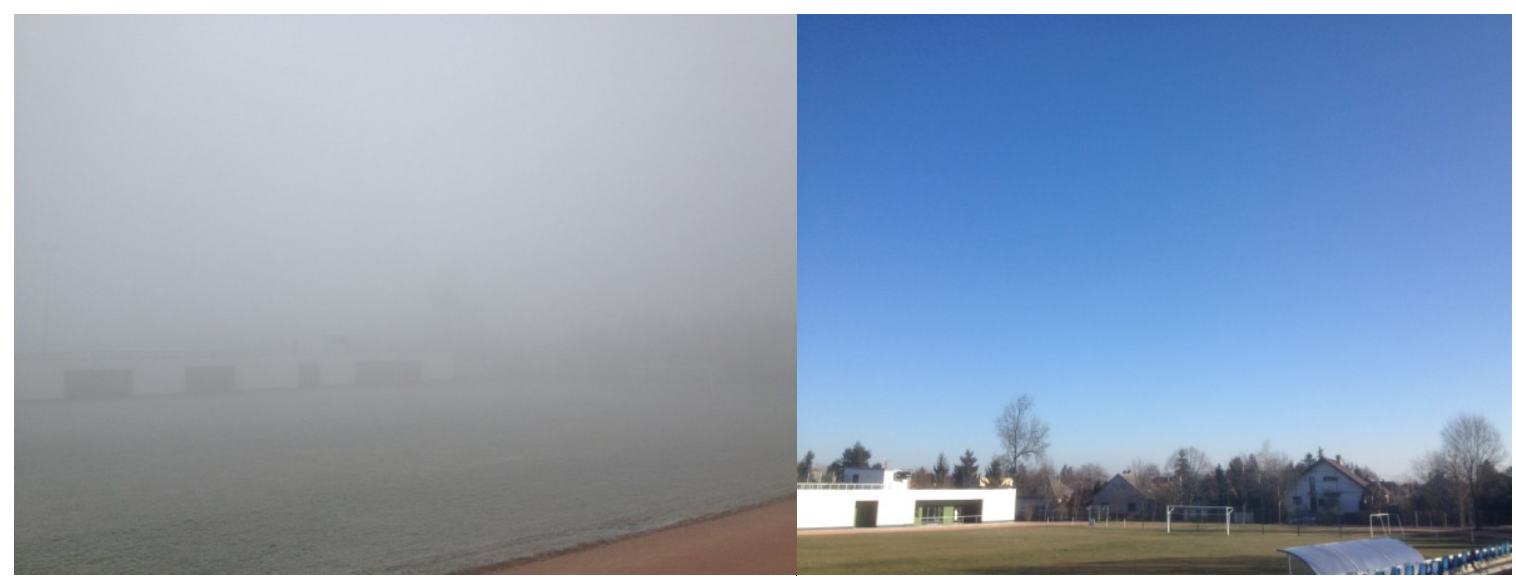

2. ábra: Az időjárás képe Martonvásáron 2017. január 1-jén 10-11 óra közötti (balra), valamint 2017. január 7-én 13-14 óra közötti időszakban (jobbra).

\section{Gondolatkisérlet}

A humán jellemzők és a légköri kényszer adatait különböző napokon gyüjtöttük, azaz a kiválasztott egy nyári és két téli napon az emberek nem voltak közvetlenül kitéve az adott napok hőterhelésének. Így a numerikus kísérletek gondolatkísérletek, a valóságban meg nem történt eseményeket szimulálnak. E gondolatkísérletek hasznossága azonban nem vonható kétségbe, a kapott eredmények akár fel is használhatók pl. kültéri sportesemények alkalmával.

\section{Eredmények}

\section{Humán jellemzök}

Nézzük előbb a humán jellemzőkből származtatott $M_{b}$ [az 1. rész (Ács, 2016) (13) és (14) képletei] és $M(1,1)$ [az 1. rész (Ács, 2016) (15) képlete; ahol az $1,1 \mathrm{~m} \cdot \mathrm{s}^{-1}$ sebesség megegyezik a $4 \mathrm{~km} \cdot$ óra $^{-1}$ sebességgel] egyén-specifikus adatokat (3. ábra)! Az ábrákon és az 1. táblázatban a személyek számozása megegyezik. Az $M_{b}$-értékek $35-45 \mathrm{~W} \cdot \mathrm{m}^{-2}$ között szóródnak, az M(1,1)-értékek szóródása viszont jóval nagyobb: 115-190 W· $\mathrm{m}^{-2}$ közöttiek. Megemlítendő, hogy a nemzetközi együttmüködésben kidolgozott UTCI ${ }^{1}$ számításakor (Blazeyczyk et al., 2010) vett $M(1,1)$-es érték $135 \mathrm{~W} \cdot \mathrm{m}^{-2}$. Megemlítendő az is, hogy az UTCI referenciaemberének Dubois-féle (Dubois \& Dubois, 1915) testfelszíne 1,86 m², míg a vizsgált tíz em-

\footnotetext{
${ }^{1}$ Universal Thermal Climate Index
} 
ber esetében ez az érték 1,52 $\mathrm{m}^{2}$ és $2,21 \mathrm{~m}^{2}$ között változott. A $d$-értékek szórása kicsi (1. táblázat).

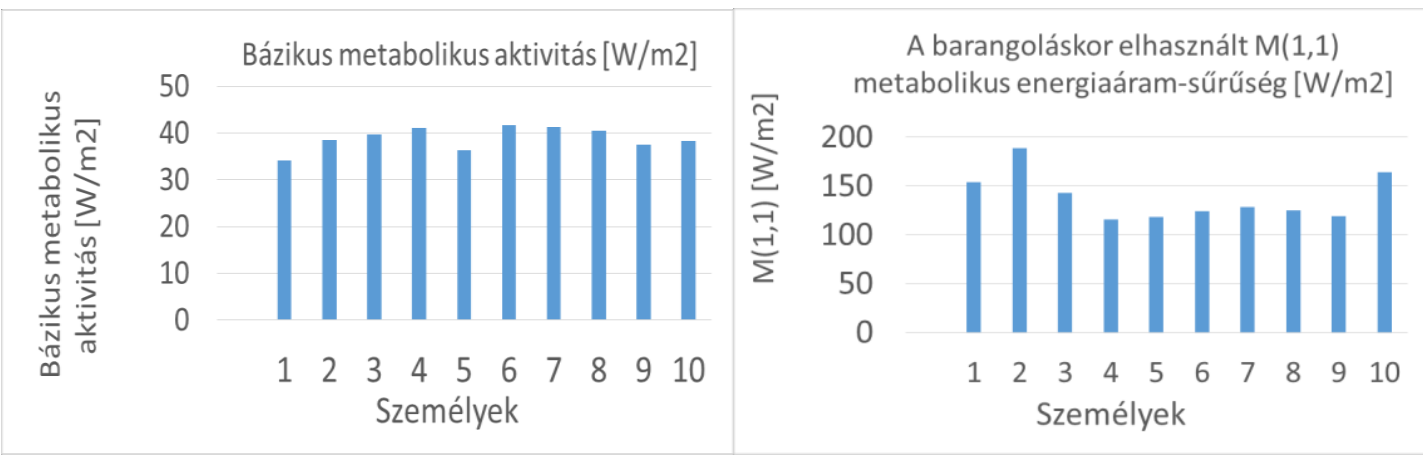

3. ábra: Tíz ember (1-10) bázikus metabolikus aktivitása és a barangoláskor elhasznált metabolikus energiaáram-sürüsége.

\section{6. augusztus 9.}

A Clo index és az operatív hőmérséklet individuális változékonyságát egy nyári hőségnapon (a napi maximális hőmérséklet nagyobb, mint $30^{\circ} \mathrm{C}$ ) a 4 . ábra szemlélteti. A Clo index értékek negatívak, ami arra utal, hogy a hőegyensúly eléréséhez hütés szükséges. Az értékek megközelítően $-0,5$ Clo és $-0,8$ Clo között szóródnak, ami majdnem 40\%-os maximális relatív eltérés. Megjegyezzük, hogy egy téli pulóver $+0,2-0,3$ Clo értékű melegítő hatást fejt ki. Az operatív hőmérsékletben szintén látható az individuális változékonyság a $d$ individuális változékonysága miatt, ami aerodinamikai hatásokra vezethető vissza. A legnagyobb abszolút eltérések $1{ }^{\circ} \mathrm{C}$ körüliek. Észrevehető az is, hogy az operatív hőmérséklet megközelíti a $40{ }^{\circ} \mathrm{C}$ ot.
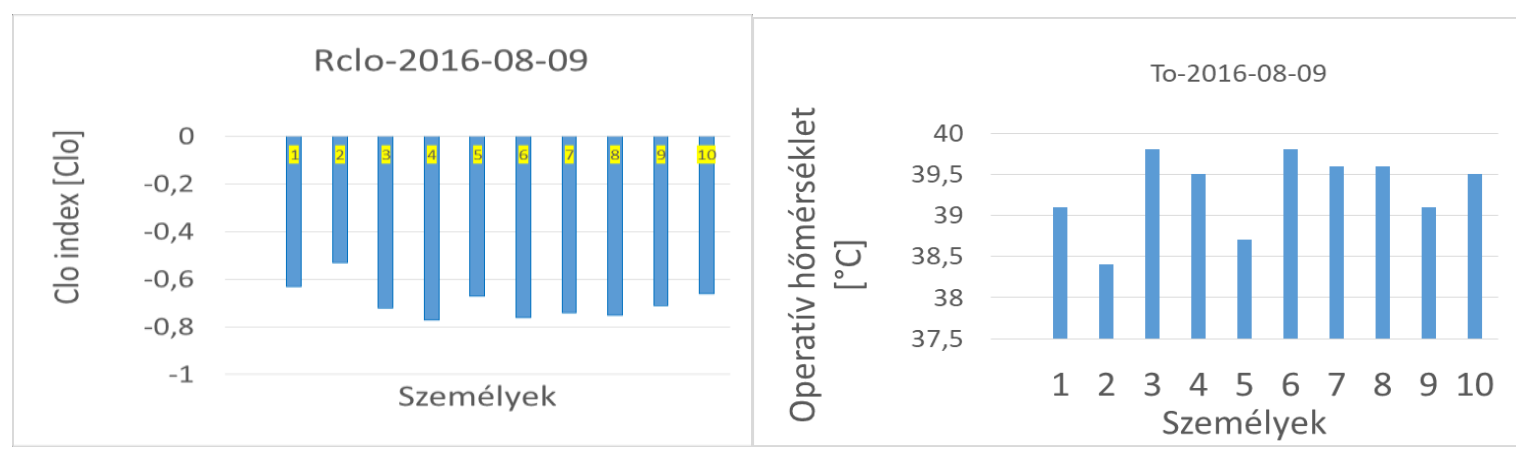

4. ábra: A Clo index [Clo] (balra) és az operatív hőmérséklet $\left[{ }^{\circ} \mathrm{C}\right]$ (jobbra) egyéni változékonysága Martonvásáron 2016. augusztus 9-én 15 és 16 óra között.

\section{7. január 1. és 7.}

Télen a Clo index pozitív, ami azt jelenti, hogy a hőhiányos kültéri környezetben fütésre van szükség a hőegyensúly eléréséhez. A Clo index egyéni változékonysága január 1-jén óriási, 0,7-1,4 közötti (5. ábra), ami maximális 50\%-os relatív eltérés. Az operatív hőmérséklet $5{ }^{\circ} \mathrm{C}$ körüli, azaz megközelítően $10^{\circ} \mathrm{C}$-kal nagyobb, mint a léghőmérséklet, ami gyönyörüen mutatja a köd melegítő hatását. A $T_{o}$ individuális változékonysága $1{ }^{\circ} \mathrm{C}$ körüli, ami szembeötlö, tekintettel a $d$ kicsi változékonyságára. A Clo index individuális változékonysága január 7-én is nagy: 1,09-1,9 közötti (6. ábra). Ezen a napon a $T_{o}$ értéke, és egyéni változékonysága is $1{ }^{\circ} \mathrm{C}$ körüli. A $T_{o} \mathrm{~kb} .10{ }^{\circ} \mathrm{C}$-kal nagyobb, mint $T_{a}$, ez a napsugárzás erős melegítő hatásával 
magyarázandó. Láthatjuk, hogy e melegítő hatás összemérhető a köd melegítő hatásával. A $T_{o}$ egyéni változékonysága igen nagy: $0,1-1,6^{\circ} \mathrm{C}$ közötti, ami kb. $90 \%$-os maximális relatív eltérés.
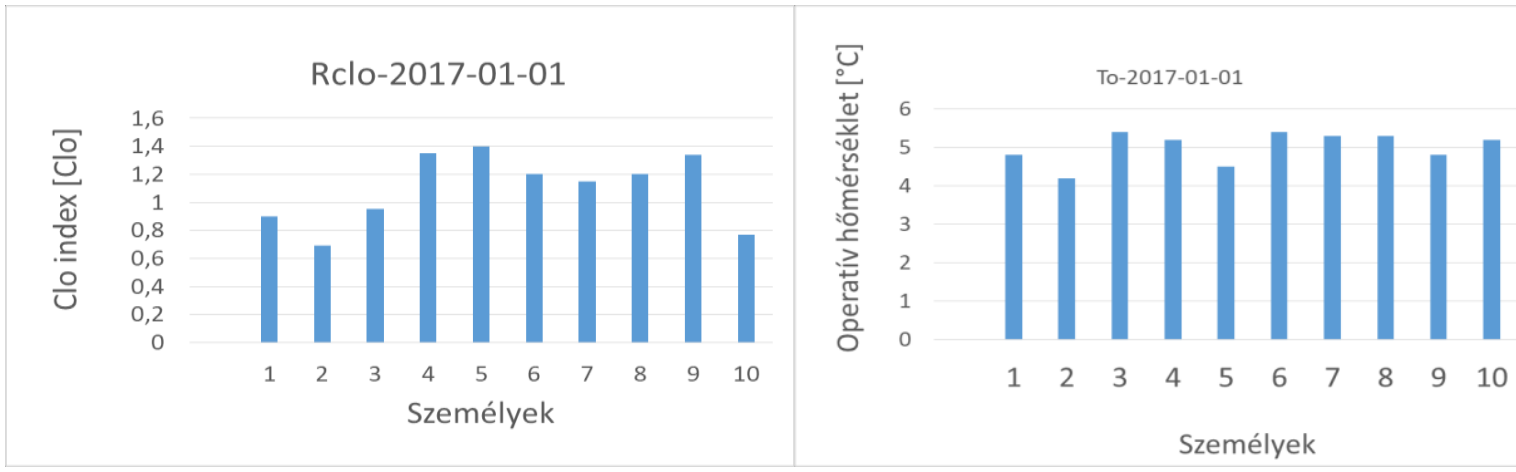

5. ábra: A Clo index [Clo] (balra) és az operatív hőmérséklet $\left[{ }^{\circ} \mathrm{C}\right]$ (jobbra) egyéni változékonysága Martonvásáron 2017. január 1-jén 11 és 12 óra között.

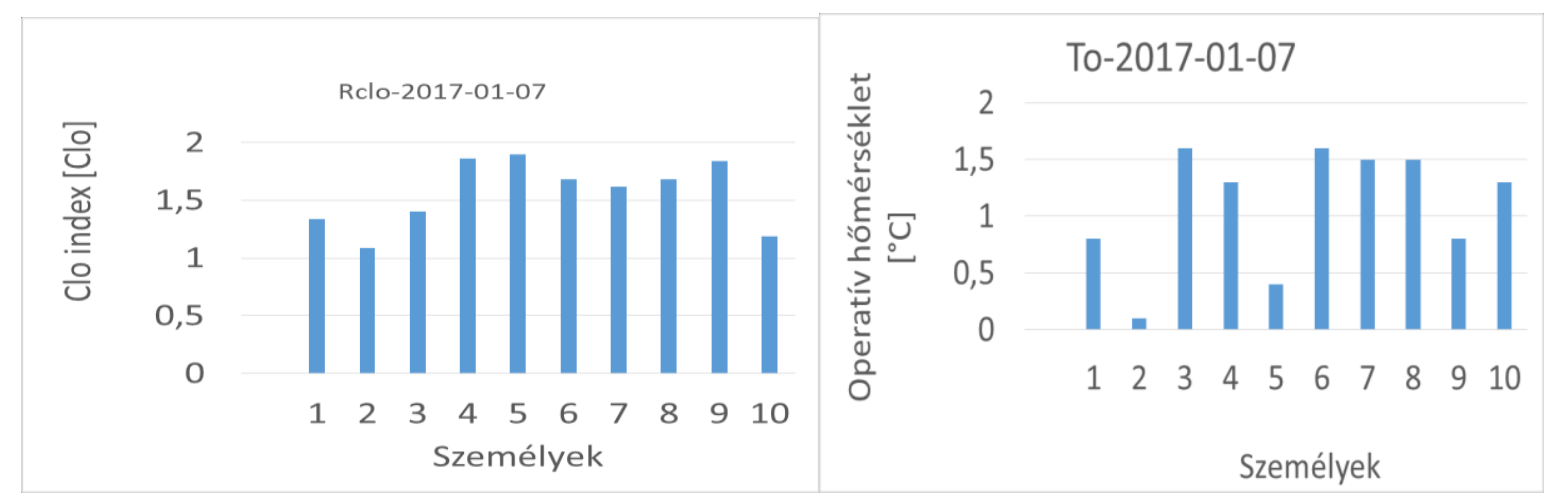

6. ábra: A Clo index [Clo] (balra) és az operatív hőmérséklet $\left[{ }^{\circ} \mathrm{C}\right]$ (jobbra) egyéni változékonysága Martonvásáron 2017. január 7-én 13 és 14 óra között.

\section{Következtetések}

Eredményeink alapján megfigyelhető, hogy

1) mind a $C l o$ index, mind a $T_{o}$ hőmérséklet egyénileg változó, ezen egyéni változékonyság a Clo index esetében szembeötlöbb;

2) a Clo index egyéni változékonysága nagyobb télen, mint nyáron, ami feltehetően azzal magyarázható, hogy a téli évszakban a sugárzási egyenleg [1. rész (Ács, 2016) (9) egyenlet] és az $M(1,1)$ értékei [1. rész (Ács, 2016) (15) egyenlet] összemérhetők.

Megjegyzendő, hogy a bemutatott eredmények csak kezdeti eredmények, a vizsgálatok tovább folytatandók minél több és különbözőbb ember bevonásával.

\section{Hivatkozások}

Ács, F., 2016: A túrázás humánmeteorológia szempontból: 1. rész: elmélet. Egyetemi Meteorológiai Füzetek, No. 27: 25-28. https://doi.org/10.31852/EMF.27.2016.025.028

Blazeyczyk, K., Broede, P., Fiala, D., Havenith, G., Holmér, I., Jendritzky, G., Kampmann, B., Kunert, A., 2010: Principles of the new Universal Thermal Climate Index (UTCI) and its application to bioclimatic research in European scale. Miscellanea Geographica, 14: 91-102. https://doi.org/10.2478/mgrsd-2010-0009 
Dubois, D., Dubois, E.F., 1915: The measurement of the surface area of Man. Arch. Intern. Med., 15: 868-881. https://doi.org/10.1001/archinte.1915.00070240077005

Jang, T.S., Iyoho, A.E., Berglund, L.G., Nair, S.S., 2009: Modeling Individual Variations in Thermal Stress Response for Human sin Transient Environments. ASHRAE Transections, 115: 552-564.

Mihailović, D.T., Ács, F., 1985: Calculation of daily amounts of global radiation in Novi Sad. Idöjárás, 89: 257-261.

\section{ORCID}

Ács F. (D) https://orcid.org/0000-0002-1611-6839 